\title{
COVID-19 Pandemic and its Impact on Dentistry: A Cross-sectional Survey of Practicing Dentists
}

\author{
Jordan J Cimilluca ${ }^{1}$, Kevin C Lee ${ }^{2}$, Steven Halepas ${ }^{3} \odot$, Bridget Ferguson ${ }^{4}$
}

\begin{abstract}
Aim and objective: The purpose of this study was to evaluate the economic impact and the dental practice changes associated with the coronavirus disease-2019 (COVID-19).

Materials and methods: This was a cross-sectional survey conducted at the peak of the COVID-19 pandemic (May 2020). The study sample was derived from the Columbia University College of Dental Medicine Alumni network, which included the graduating classes between 1975 and 2015. Active dental practitioners were surveyed regarding changes to their current operations and protective safety measures through a 22 closed-ended questionnaire-based survey.

Results: The response rate was $17 \%$. Nearly $70.92 \%$ of respondents laid off at least one staff member during the COVID-19 pandemic, $51.80 \%$ expressed fear of permanent closure, and $79.43 \%$ applied for a small business administration loan. There were no significant associations between the amount of time in practice and the need to lay off staff members, the fear of going out of business, or the rates of application for the small business administration loan. Many practitioners bought at least one device geared toward reducing COVID-19 transmission, such as ultraviolet (UV) lights (26.21\%), extraoral suctions (37.31\%), and high-efficiency particulate air (HEPA) air filters (54.55\%).

Conclusion: At the peak of the pandemic, the majority of dental providers had to reduce staff and seek financial assistance. Concurrently, many of these practices also invested in new safety equipment with the intention of reducing viral transmission.

Clinical significance: External mouth suctions, commercial air purifiers, and air exchange devices might be useful in the private practice setting. However, financially strained practitioners should recognize that these devices have not currently been proven to be effective against the COVID-19 virus.

Keywords: COVID-19, Personal protective equipment, Practice management.

The Journal of Contemporary Dental Practice (2021): 10.5005/jp-journals-10024-3092
\end{abstract}

\section{INTRODUCTION}

The coronavirus disease-2019 (COVID-19) pandemic has created many global economic challenges. During these trying times, small business owners have suffered the most significant economic disturbances. Many small businesses in the United States have had to temporarily suspend their operations in order to oblige stay-at-home orders from their local governments. As a result of lost revenue, many small businesses have become dependent on federal stimulus money, such as the Coronavirus Aid, Relief, and Economic Security (CARES) Act, to stay afloat. ${ }^{1}$ Thousands of businesses have had to lay off their staff, and as of the time of this investigation, the unemployment rate is approaching $15 \%$. For reference, this is nearly double the unemployment rate observed during the great recession of 2008 and 2009. ${ }^{2}$ The intense surge in unemployment also carries a variety of downstream health care implications. Medical and dental insurance is often tied to employment. Furthermore, many patients use their disposable income for dental treatment due to inadequate or nonexistent dental insurance coverages. ${ }^{3}$

Despite the injection of federal relief to combat economic instability, there remains a high probability that many small businesses will be unable to reopen once the viral spread is better controlled. Private health care offices are not immune to these struggles, and it is possible that an acute shortage of providers may result from office closures. ${ }^{4}$ Dental providers are at particular risk because their procedures carry a high risk for viral spread, and most providers operate in a private small business model. Unemployment data released by the Bureau of Labor Statistics
${ }^{1}$ College of Dental Medicine, Columbia University, New York, New York, United States

${ }^{2-4}$ Department of Oral and Maxillofacial Surgery, New YorkPresbyterian/Columbia University Irving Medical Center, New York, United States

Corresponding Author: Steven Halepas, Department of Oral and Maxillofacial Surgery, New York-Presbyterian/Columbia University Irving Medical Center, New York, United States, Phone: +2123057626, e-mail: steve.halepas@gmail.com

How to cite this article: Cimilluca JJ, Lee KC, Halepas S et al. COVID-19 Pandemic and its Impact on Dentistry: A Cross-sectional Survey of Practicing Dentists. J Contemp Dent Pract 2021;22(5):473-478.

Source of support: Nil

Conflict of interest: None

indicate that health care employment in the United States (US) declined by 1.4 million during the month of April 2020. Employment losses in dental offices contributed most heavily to this figure, accounting for 503,000 lost jobs. ${ }^{5}$ An acute shortage of dental providers is most likely to be observed in areas of the country that have been hardest hit by the pandemic. New York State (NYS) has been designated the epicenter of the pandemic because of both the high overall positivity rate and the impressive density of disease burden in the New York City metropolitan area. ${ }^{6}$ Not surprisingly, during the week of April 20,2020,59.4\% of dental practices in NYS were not paying any staff. ${ }^{7}$ 
Personal protective equipment (PPE) shortages and expenses not only affect the profitability but also appear to be the ratelimiting factor for resuming normal dental activities. Some dental practices have continued to accept emergency patients throughout the stay-at-home period in an attempt to off-load emergency department visits, as well as bandage some of the financial hemorrhages their businesses are undoubtedly experiencing. Unfortunately, certain barriers have made providing dental care a challenge in the COVID-19 environment. At the peak of the pandemic, private dental practices were experiencing an initial delay in obtaining appropriate PPE. This meant that there was a latent period when dental care could not be provided to emergency patients despite provider willingness and availability. ${ }^{8}$ PPE was also an increasingly scarce public resource as it was stockpiled in hospital supply rooms. This led to substantial price gouging by third-party vendors.

History has demonstrated that public health crises generally usher in new standards of PPE practices. Unfortunately, this pandemic has ushered in a surge of fear-based marketing tactics that target vulnerable dentists. Many of the protective devices offered by medical manufactures have little to no evidence base to support their efficacy against COVID-19 transmission. These include ultraviolet lights, extraoral suctions, and high-efficiency particulate air (HEPA) filters. Given the current landscape, it is important to appraise the value of PPE items as the pandemic has in all likelihood already placed heavy financial stresses on dental practices. The purpose of this study was to conduct a crosssectional survey of dentists in order to evaluate the economic and safety impact of COVID-19 on dental practices at the height of the pandemic.

\section{Matterials and Methods}

This was a cross-sectional survey of the Columbia University College of Dental Medicine Alumni network, which included the graduating classes between 1975 and 2015. Qualtrics Research Services (www.qualtrics.com) were used to publish and administer the study survey through email requests. The first survey request was sent to Columbia alumni on May 17, 2020. A second follow-up email was repeated on May 22, 2020, and the survey remained open until May 25, 2020. Survey participants were required to be practicing dentists, and the survey was comprised of 22 closed-ended questions that obtained information regarding provider characteristics, the economic impact of an office closure, and any advanced PPE purchases prompted by the pandemic.

Specifically, participants were asked to provide their years in practice, job title, and dental specialty. Regarding the economic impact of COVID-19, respondents were asked about changes to their office operations, applications for small business administration loans under the CARES Act, disability benefits, and concerns for permanent office closure. Regarding safety practices, respondents were asked about changes in PPE, any new practice expenditures (UV lights, extraoral suctions, HEPA filter, and negative pressure rooms), and their personal views toward the effectiveness of these new safety measures.

Descriptive analyses and chi-square tests were performed where appropriate using SAS ${ }^{\circledast}$ Studios, and statistical significance was set at $p<0.05$. This study was conducted with the approval and compliance of the Columbia University Irving Medical Center's
Institutional Review Board (protocol AAAT0509), and informed consent was obtained from all study participants.

\section{Results}

Overall 2,871 practitioners were contacted via email, and 878 practitioners opened the email. Among those who opened the email, 151 complete responses were recorded (17\%). Survey respondents were in different stages of their careers and spread across multiple dental specialties (Table 1). Many dentists saw emergency patients in their offices during the pandemic (66.89\%). And $66.23 \%$ of respondents had to lay off at least one staff member due to the COVID-19 pandemic (Table 2). There was no significant association between time in practice and the need to lay off staff members $(p=0.83)$. Similarly, there was no association between time in practice and fear of going out of business ( $p=0.33$ ) or rate of applications for the small business administration loan under the CARES Act $(p=0.18)$ (Table 3). Nearly $2.65 \%$ of respondents stated they had to permanently close at least one of their office locations because of the pandemic's economic effects. Half (47.68\%) of the respondents feared going out of business in the future. While $74.17 \%$ of respondents applied for the small business administration loan under the CARES Act, $64.90 \%$ of respondents were approved. Only $7.28 \%$ applied for disability benefits to cover costs during the pandemic, and only $1.99 \%$ received disability benefits.

Table 1: Characteristics of survey respondents

\begin{tabular}{|c|c|c|}
\hline Q1 How long have you been in practice? & $N$ & $\%$ \\
\hline$<5$ years & 14 & 9.30 \\
\hline $5-10$ years & 32 & 21.20 \\
\hline $11-20$ years & 33 & 21.90 \\
\hline $21-30$ years & 31 & 20.50 \\
\hline$>31$ years & 37 & 24.50 \\
\hline I prefer not to answer & 2 & 1.30 \\
\hline Unanswered & 2 & 1.30 \\
\hline \multicolumn{3}{|l|}{ Q2 What best describes your role? } \\
\hline Practice owner & 110 & 72.85 \\
\hline Associate & 24 & 15.89 \\
\hline Other & 13 & 8.61 \\
\hline Declined to answer & 4 & 2.65 \\
\hline \multicolumn{3}{|l|}{ Q3 Dental specialty } \\
\hline Dental anesthesiology & 0 & 0.00 \\
\hline Dental public health & 1 & 0.70 \\
\hline Endodontics & 10 & 6.60 \\
\hline General dentistry & 63 & 41.70 \\
\hline Oral pathology & 1 & 0.70 \\
\hline Oral radiology & 0 & 0.00 \\
\hline Oral surgery & 18 & 11.90 \\
\hline Oral medicine & 0 & 0.00 \\
\hline Orofacial pain & 0 & 0.00 \\
\hline Orthodontics & 17 & 11.30 \\
\hline Pediatric dentistry & 16 & 10.60 \\
\hline Periodontics & 14 & 9.30 \\
\hline Prosthodontics & 4 & 2.60 \\
\hline Unanswered & 7 & 4.60 \\
\hline
\end{tabular}


COVID-19 Pandemic and Dentistry

Table 2: Survey questions investigating the economic impact of COVID-19 on dental practice

\begin{tabular}{|c|c|c|c|c|c|}
\hline & $n$ & $\%$ & & $n$ & $\%$ \\
\hline $\begin{array}{l}\text { Q4 Did you see emergency patients in your } \\
\text { practice through the COVID-19 pandemic? }\end{array}$ & & & $\begin{array}{l}\text { Q9 Were you approved for the small business } \\
\text { loan? }\end{array}$ & & \\
\hline Yes & 101 & 66.89 & Yes & 98 & 64.90 \\
\hline No & 40 & 26.49 & No & 36 & 23.84 \\
\hline Unanswered & 10 & 6.63 & Unanswered & 17 & 11.26 \\
\hline $\begin{array}{l}\text { Q5 Did you close your office during the } \\
\text { COVID-19 pandemic? }\end{array}$ & & & $\begin{array}{l}\text { Q10 Did you apply for disability benefits to cover } \\
\text { costs during the pandemic? }\end{array}$ & & \\
\hline Yes & 56 & 37.08 & Yes & 11 & 7.28 \\
\hline No - open for emergency patients only & 88 & 58.28 & No & 127 & 84.11 \\
\hline Unanswered & 7 & 4.64 & Unanswered & 13 & 8.61 \\
\hline $\begin{array}{l}\text { Q6 Did you have to lay off at least one staff } \\
\text { member because of the COVID-19 pandemic? }\end{array}$ & & & $\begin{array}{l}\text { Q11 Did you receive disability benefits to cover costs } \\
\text { during the pandemic? }\end{array}$ & & \\
\hline Yes & 100 & 66.23 & Yes & 3 & 1.99 \\
\hline No & 41 & 27.15 & No & 134 & 88.74 \\
\hline Unanswered & 10 & 6.62 & Unanswered & 14 & 9.27 \\
\hline $\begin{array}{l}\text { Q7 Did you reduce the hours your practice was } \\
\text { open during the COVID-19 pandemic? }\end{array}$ & & & $\begin{array}{l}\text { Q12 Did any of your locations go out of business as } \\
\text { a result of the COVID-19 pandemic? }\end{array}$ & & \\
\hline Yes & 137 & 90.73 & Yes & 4 & 2.65 \\
\hline No & 4 & 2.65 & No & 133 & 88.08 \\
\hline Unanswered & 10 & 6.62 & Unanswered & 14 & 9.27 \\
\hline $\begin{array}{l}\text { Q8 Did you apply for the small business } \\
\text { administration loan under the CARES Act? }\end{array}$ & & & $\begin{array}{l}\text { Q13 Do you fear going out of business in the future } \\
\text { as a result of the COVID-19 pandemic? }\end{array}$ & & \\
\hline Yes & 112 & 74.17 & Yes & 72 & 47.68 \\
\hline No & 29 & 19.21 & No & 67 & 44.37 \\
\hline Unanswered & 10 & 6.62 & Unanswered & 12 & 7.95 \\
\hline
\end{tabular}

Table 3: Effect of clinical experience on practice changes

\begin{tabular}{|c|c|c|c|c|c|c|}
\hline & Laid off staff & $p$ value & $\begin{array}{l}\text { Applied for } \\
\text { SBA loan }\end{array}$ & $p$ value & $\begin{array}{l}\text { Fear of going out } \\
\text { of business }\end{array}$ & $p$ value \\
\hline Years in practice & & 0.83 & & 0.18 & & 0.33 \\
\hline$<5$ years & $5.00 \%$ & & $5.00 \%$ & & $2.17 \%$ & \\
\hline $5-10$ years & $14.29 \%$ & & $15.71 \%$ & & $11.59 \%$ & \\
\hline $11-20$ years & $17.14 \%$ & & $22.14 \%$ & & $12.32 \%$ & \\
\hline $21-30$ years & $16.43 \%$ & & $16.43 \%$ & & $9.42 \%$ & \\
\hline$>31$ years & $17.14 \%$ & & $19.29 \%$ & & $15.94 \%$ & \\
\hline I prefer not to answer & $0.71 \%$ & & $0.71 \%$ & & $0.00 \%$ & \\
\hline
\end{tabular}

There were substantial changes to safety practices during the crisis (Table 4). While $78.36 \%$ of respondents report implementing N95 masks with every patient, 5.97\% stated they use powered airpurifying respirators (PAPRs). Many practitioners have bought at least one device geared toward reducing COVID-19 transmission, such as a UV light (26.21\%), extraoral suctions (37.31\%), and office HEPA air filters (54.55\%). Similarly, $69.92 \%$ of respondents stated these devices would be a good marketing tool, and $54.48 \%$ believed they would actually reduce the transmission of COVID-19 in their practice. There was a significant association between those who believed devices, such as HEPA filters, UV lights, and extraoral suctions, would be good marketing tools and those who purchased UV lights $(p<0.01)$ and HEPA air filters $(p=0.03$ ) (Table 5). Surprisingly, there was no association between those who believed devices, such as HEPA filters, UV lights, and extraoral suctions, would be good marketing tools and those who purchased extraoral suctions $(p=0.15)$. There was a significant association between those who believed devices, such as HEPA filters, UV lights, and extraoral suctions, would reduce COVID-19 transmission and those who purchased UV lights $(p<0.01)$, extraoral suctions $(p<0.01)$, and HEPA filters $(p<0.01)$.

\section{Discussion}

Although no COVID-19 cases have been directly linked to a dental setting, there is sufficient biologic plausibility for viral spread via generated aerosols. Therefore, special precautions to mitigate the risk of spread may be necessary for dental practices. ${ }^{9}$ Some of these special precautions, in addition to the more generalized use of enhanced PPE as discussed earlier, may include negative pressure environments with high-quality air filters, UV sanitation, and air exchange rates of at least 12 air changes per hour. ${ }^{4,9,10}$ This study confirmed that many dental practices experienced temporary closures and sought financial assistance during the pandemic. Furthermore, many providers reflexively purchased advanced 
COVID-19 Pandemic and Dentistry

Table 4: Survey questions investigating the safety impact of COVID-19 on dental practice

\begin{tabular}{|c|c|c|c|c|c|}
\hline & $n$ & $\%$ & & $n$ & $\%$ \\
\hline $\begin{array}{l}\text { Q14 Did you change your personal } \\
\text { protective equipment practices due to } \\
\text { the pandemic? }\end{array}$ & & & $\begin{array}{l}\text { Q18 In light of the COVID-19 pandemic, have you } \\
\text { considered turning an operatory into a negative } \\
\text { pressure room? }\end{array}$ & & \\
\hline N95 & 105 & 78.36 & Yes & 20 & 15.04 \\
\hline PAPRs & 8 & 5.97 & No & 113 & 84.96 \\
\hline No & 21 & 15.67 & $\begin{array}{l}\text { Q19 Would turning an operatory into a negative } \\
\text { pressure room be a significant financial burden for you } \\
\text { or your practice? }\end{array}$ & & \\
\hline $\begin{array}{l}\text { Q15 Have you bought at least one UV light } \\
\text { device to aid in the prevention of COVID-19? }\end{array}$ & & & Yes & 117 & 87.97 \\
\hline Yes & 35 & 26.21 & No & 16 & 12.03 \\
\hline No & 99 & 73.88 & $\begin{array}{l}\text { Q20 Do you believe the purchase of any of these } \\
\text { devices (HEPA filter, UV light, extraoral suctions, and } \\
\text { PAPRs) would benefit in marketing to patients? }\end{array}$ & & \\
\hline $\begin{array}{l}\text { Q16 Have you bought at least one extraoral } \\
\text { aerosol suction devices for your office due to } \\
\text { the COVID-19 pandemic? }\end{array}$ & & & Yes & 93 & 69.92 \\
\hline Yes & 50 & 37.31 & No & 40 & 30.08 \\
\hline No & 84 & 62.69 & $\begin{array}{l}\text { Q21 Do you believe the purchase of any of these } \\
\text { devices (HEPA filter, UV light, extraoral suctions, and } \\
\text { PAPRs) would actually reduce the transmission of } \\
\text { COVID-19 in your practice? }\end{array}$ & & \\
\hline $\begin{array}{l}\text { Q17 Have you bought at least one HEPA } \\
\text { air filter for your office due to the COVID-19 } \\
\text { pandemic? }\end{array}$ & & & Yes & 73 & 54.48 \\
\hline Yes & 72 & 54.55 & No & 61 & 45.52 \\
\hline No & 60 & 45.45 & & & \\
\hline
\end{tabular}

Some respondents did not answer each question and were omitted

Table 5: Comparison of device purchases by belief in practice benefit and belief in transmission benefit

\begin{tabular}{lcccccc}
\hline & UV lights & $p$ value & Extraoral suctions & pvalue & HEPA filters & $p$ value \\
\hline Marketing benefit & & $<0.01$ & & 0.15 & & 0.03 \\
Yes & $22.90 \%$ & & $28.24 \%$ & & $42.31 \%$ & \\
No & $3.05 \%$ & & $8.4 \%$ & & $12.31 \%$ & \\
Reduced transmission benefit & & $<0.01$ & & $<0.01$ & & $<0.01$ \\
Yes & $20.45 \%$ & & $28.79 \%$ & & $38.93 \%$ & \\
No & $6.06 \%$ & & $8.33 \%$ & & $16.03 \%$ & \\
\hline
\end{tabular}

safety equipment and believed that these devices would indeed reduce transmission.

While the aforementioned special precautions are likely unnecessary for patients without laboratory evidence of an active COVID-19 infection, as well as those who have developed immunity and are not shedding the virus, it is understandable that private dental practitioners may feel the need to take special precautions by restructuring the air filtration of their offices, referring patients to major medical centers capable of handling COVID-19 patients, or by simply remaining closed. These concerns are likely to remain until a COVID-19 vaccine is approved and widely disseminated, and rapid COVID-19 test kits are commercially available to private dental practices, and guidelines are released from health organizations regarding the necessity of special precautions in a private dental setting.

The concerns over the implementation of special precautions in private dental offices have obvious financial implications, as do the rapid COVID-19 test kits, which may eventually become a requirement for dental offices. The Paycheck Protection Program is a loan forgiveness program meant to incentivize small businesses to pay employees, rent, mortgage, and utilities. As of April 10, 2020, only $7.8 \%$ of US small businesses have been approved for funding. ${ }^{11}$ Fortunately, $79.4 \%$ of the dentists surveyed had applied for the small business administration loan under the CARES Act, and $71.13 \%$ of the dentists were also approved. While this financial aid to small businesses offsets some of the pandemic losses, practitioners should be cautious about investing heavily in new technologies marketed toward combating COVID-19 as none have been proven to be completely effective at the time of this investigation.

More than half of the surveyed practitioners had recently bought advanced HEPA filters for their office. Generally, HEPA filter particles are as small as 0.3 microns, but the coronavirus responsible for COVID-19 is 0.125 microns in size. ${ }^{12}$ Therefore, high-risk procedures that generate bio-aerosols may require filters with ultra low penetration air (ULPA) efficiency ratings, capable of filtering particles as small as 0.1 microns. ${ }^{12}$ Alternatively, HEPA 
filters with $0.023 \mu \mathrm{m}$ pore sizes have shown $99.9 \%$ effectiveness at removing SARS-CoV-2 aerosols, so these HEPA filters may be another option. ${ }^{13}$ When COVID-19 particles are aerosolized with water, the particles become larger and could theoretically be filtered by the standard HEPA filter size.

Only $26.21 \%$ of survey participants had bought at least one UV light device for their office. It has been shown that electron virus magnetic radiation in the UV-C spectrum (100-280 nm) has the greatest germicidal efficacy. ${ }^{14,15}$ Thanks to the work of Bedell and colleagues, it is now known that whole room UV-C disinfection systems are efficacious in reducing the number of RNA viral particles on surfaces. ${ }^{16}$ Drastic reductions of middle eastern respiratory syndrome coronavirus (MERS-CoV) particles have been seen after 10 minutes of UV-C exposure, and $>99.999 \%$ reductions of MERS-CoV droplets have been seen after just 5 minutes. Despite being the most biologically active radiation, UV-C wavelengths are in fact much less dangerous to humans because they are preferentially absorbed by dead skin cells. In contrast, UV-B and UV-A penetrate deeper through the epithelium to reach live skin cells. ${ }^{17,18}$ The practicality and safety of UV-C irradiation is obviously a benefit to private practice clinicians who may be considering air sanitation devices with UV-C capabilities. Currently, there is no consensus as to the environmental implications of these UV-C devices, and no studies to date have evaluated their specific effects on the COVID-19 virus.

While only $5.97 \%$ of those surveyed have PAPRs, over $78.36 \%$ are routinely using N95. To protect individuals from COVID-19 infections, the National Institute for Occupational Safety and Health (NIOSH) has placed considerable emphasis on the importance of using respirators capable of filtering $>95 \%$ of aerosol particles $<5$ microns in diameter. The $\mathrm{N} 95$ mask fulfills these requirements. Currently, PPE guidelines for aerosol-generating procedures state that PAPRs are superior to NIOSH-certified and fit-tested N95s. PAPRs are battery-powered blowers that provide positive airflow through a filter to a facepiece, and the types of filters used depend on the type and amount of airborne contaminant. ${ }^{19}$ Some additional advantages of PAPRs over N95s are that they provide coverage of the head and protect the conjunctiva, another potential route for viral entry. Furthermore, because they have a full hood, PAPRs do not require fit-testing and are compatible with facial hair. ${ }^{19}$ The complexities associated with PAPRs do require specific training protocols with respect to donning and doffing, and improper handling risks self-contamination. In fact, the Centers for Disease Control and Prevention actually maintains that N95s are preferable to PAPRs because they are disposable and therefore more sanitary. ${ }^{20}$

Surveyed dentists (37.31\%) have always purchased extraoral suction devices for their offices. Several companies are attempting to capitalize on the uncertainty surrounding COVID-19, dental bioaerosols, and air filtration marketing extraoral suction devices that may or may not be useful against aerosolized viruses. Teanpaisan et al. modified a household vacuum cleaner into an extraoral vacuum aspirator (EOVA) to reduce bacteria spread from dental aerosols. ${ }^{21}$ EOVAs show promise in dental settings, but a more thorough body of literature needs to be established. No studies have demonstrated the benefit of extraoral suctions with viral particles. Until more rigorous research is conducted, companies will continue to sell these devices as long as demand is present.

There are several limitations of this study. First, our understanding and management of COVID-19 is constantly evolving. Any research on this topic is limited by the available data at the time of inquiry and runs the risk of becoming a historical communication once new breakthroughs emerge. This paper attempts to capture a snapshot of the dental landscape at the height of the pandemic between April and June 2020. In an effort to capture responses at the peak of the pandemic, the survey was disseminated quickly and was available for only a short period of time. Although waiting longer would have improved the response rate and reduced bias, we felt that it was also important to expedite our project and distribute our results as soon as possible in the COVID-19 landscape. This was a sentiment shared by our institution's ethical review board, which made efforts to hasten the approval process for studies investigating COVID-19.

\section{ConClusion}

Pandemics inflict devastating consequences on communities and cause long-standing effects on the economy and health-care system. External mouth suctions, commercial air purifiers, and air exchange devices may be useful for this purpose; however, rigorous studies have not definitively proven that they are any more effective than social distancing, PPE, and standard hand hygiene. Practitioners who are financially strained should be cautious when purchasing new safety equipment during such an uncertain time, particularly when many of these devices lack solid evidence to support their efficacy.

\section{OrCID}

Steven Halepas 이 https://orcid.org/0000-0002-6141-6371

\section{References}

1. S.3548 CARES Act, 116th US Congress Sess.; 2020.

2. Civilian unemployment rate. US Department of Labor; 2020.

3. How the COVID-19 recession could affect health insurance coverage [press release]. Robert Wood Johnson Foundation; 2020.

4. Ferneini EM. The financial impact of COVID-19 on our practice. J Oral Maxillofac Surg 2020;78(7):1047-1048. DOI: 10.1016/j.joms.2020.03.045.

5. The employment situation - April 2020 [press release]. US Department of Labor; 2020.

6. Breslin N, Baptiste C, Gyamfi-Bannerman C, et al. COVID-19 infection among asymptomatic and symptomatic pregnant women: two weeks of confirmed presentations to an affiliated pair of New York City hospitals. Am J Obstet Gynecol 2020;100118. DOI: 10.1016/j. ajogmf.2020.100118.

7. HPI. COVID-19: economic impact on dental practices. American Dental Association; 2020.

8. Ferneini EM, Halepas S. Protecting ourselves during the COVID-19 pandemic. J Oral Maxillofac Surg 2020;78(8):1227-1228. DOI: 10.1016/j. joms.2020.04.047.

9. Ge ZY, Yang LM, Xia JJ, et al. Possible aerosol transmission of COVID-19 and special precautions in dentistry. J Zhejiang Univ Sci B 2020;21(5):361-368. DOI: 10.1631/jzus.B2010010.

10. Szeto $W$, Yam WC, Huang $H$, et al. The efficacy of vacuum-ultraviolet light disinfection of some common environmental pathogens. BMC Infect Dis 2020;20(1):127. DOI: 10.1186/s12879-020-4847-9.

11. Goodshore C. Paycheck protection program guide: coronavirus relief loans for small business: business.org; April 10, 2020. Available from: https://www.business.org/finance/loans/paychex-protectionprogram-guide/\#PPP_Funding_Across_America_.

12. David AP, Jiam NT, Reither JM, et al. Endoscopic skull base and transoral surgery during the COVID-19 pandemic: minimizing droplet spread with a negative-pressure otolaryngology viral isolation drape (NOVID). Head Neck 2020;42(7):1577-1582. DOI: 10.1002/hed.26239.

13. Tsai YH, Wan GH, Wu YK, et al. Airborne severe acute respiratory syndrome coronavirus concentrations in a negative-pressure isolation room. Infect Control Hosp Epidemiol 2006;27(5):523-525. DOI: $10.1086 / 504357$. 
14. Hertel E. Über die Beeinflussung des Organismus durch Licht, speziell durch chemisch wirksame Strahlen. Zeitschr f allg Phys Bd 1904;4.

15. Hertel E. Ueber physiologische Wirkung von Strahlen verschiedener Wellenlänge. Zeitschr f allg Physiol 1905;5:95-122.

16. Bedell K, Buchaklian AH, Perlman S. Efficacy of an automated multiple emitter whole-room ultraviolet- $C$ disinfection system against coronaviruses MHV and MERS-CoV. Infect Control Hosp Epidemiol 2016;37(5):598-599. DOI: 10.1017/ice.2015.348.

17. Reed NG. The history of ultraviolet germicidal irradiation for air disinfection. Public Health Rep 2010;125(1):15-27. DOI: 10.1177/ 003335491012500105.

18. Bruls WA, Slaper H, van der Leun JC, et al. Transmission of human epidermis and stratum corneum as a function of thickness in the ultraviolet and visible wavelengths. Photochem Photobiol 1984;40(4):485-494. DOI: 10.1111/j.1751-1097.1984.tb04622.x.

19. Roberts V. To PAPR or not to PAPR? Can J Respir Ther 2014;50(3):87-90. PMID: 26078617

20. Boskoski I, Gallo C, Wallace MB, et al. COVID-19 pandemic and personal protective equipment shortage: protective efficacy comparing masks and scientific methods for respirator reuse. Gastrointest Endosc 2020;92(3):519-523. DOI: 10.1016/j.gie.2020.04.048.

21. Teanpaisan R, Taeporamaysamai M, Rattanachone $\mathrm{P}$, et al. The usefulness of the modified extra-oral vacuum aspirator (EOVA) from household vacuum cleaner in reducing bacteria in dental aerosols. Int Dent J 2001;51(6):413-416. DOI: 10.1002/j.1875-595x.2001. tb00853.x. 